IWONA ŻUR

EWA DUBAS

SABINA MALAGA

FRANCISZEK JANOWIAK

ANNA JANECZKO

MARCIN RAPACZ

TOMASZ HURA

PIOTR WALIGÓRSKI

AGNIESZKA OSTROWSKA

MAGDALENA WÓJCIK-JAGŁA

Instytut Fizjologii Roślin Polskiej Akademii Nauk w Krakowie

Kierownik Tematu: dr hab. Iwona Żur Instytut Fizjologii Roślin Polskiej Akademii Nauk w Krakowie

ul. Niezapominajek 21, 30-239 Kraków, tel. +48 12 4253301, e-mail: i.zur@ifr-pan.edu.pl

Prace zostały wykonane $w$ ramach badan podstawowych na rzecz postępu biologicznego $w$ produkcji roślinnej na podstawie decyzji Ministra Rolnictwa $i$ Rozwoju Wsi nr HOR.hn.802.15.2018, Zadanie 26.

\title{
Identyfikacja czynników determinujących odporność jęczmienia ozimego (Hordeum vulgare L.) na suszę i mróz
}

\section{Identification of factors which determine drought and freezing tolerance in barley (Hordeum vulgare L.)}

Słowa kluczowe: abiotyczne czynniki stresowe, hartowanie, jęczmień ozimy, mrozoodporność, susza, tolerancja

Jęczmień ozimy jest gatunkiem zboża o wysokim potencjale plonotwórczym i ziarnie o dużej wartości paszowej i użytkowej. Potencjalnie wysoka wydajność tego zboża jest jednak znacząco obniżana przez niską zimotrwałość tego gatunku, wynikającą przede wszystkim z jego niskiej odporności na mróz. Ogranicza to areał uprawy jęczmienia ozimego do rejonów o łagodniejszym klimacie. Innym czynnikiem wpływającym na obniżenie plonowania jest susza glebowa, zwłaszcza w okresie największego zapotrzebowania na wodę, od kwietnia do czerwca. Susza w tym okresie powoduje u jęczmienia znaczne obniżenie liczby kłosów oraz liczby ziaren w kłosie i co za tym 
idzie znaczący spadek plonowania. Z tych względów, identyfikacja czynników determinujących tolerancję na suszę i mróz oraz opracowanie wiarygodnych procedur selekcji roślin o zwiększonej tolerancji na te czynniki stresowe jest bardzo istotne i może w znaczący sposób ograniczyć straty plonowania oraz zwiększyć areał uprawy jęczmienia ozimego. Ze względu na fakt, iż zarówno mrozoodporność jak i odporność na suszę są cechami złożonymi, warunkowanymi przez szereg genów o zróżnicowanym sposobie dziedziczenia i interakcjach, strategia piramidyzacji korzystnych genów wydaje się być najbardziej odpowiednia. Jednak korzystny układ wielu alleli leżących u podłoża odporności ilościowej może zostać zaburzony wskutek rekombinacji w kolejnych pokoleniach. Jedną z możliwości ominięcia tego problemu jest wykorzystanie technologii podwojonych haploidów (ang. doubled haploids, DH), umożliwiającej wyprowadzenie całkowicie homozygotycznych linii $\mathrm{z}$ heterozygotycznego materiału w ciągu jednego pokolenia. Inną korzyścią wynikającą z zastosowania technologii DH jest możliwość znacznego poszerzenia zakresu zmienności badanych cech, wynikająca z ekspresji alleli recesywnych oraz nowych plejotropowych i epistatycznych interakcji międzygenowych.

Celem projektu była identyfikacja fizjologicznych, metabolomicznych i molekularnych podstaw adaptacji jęczmienia ozimego do temperatur mrozowych oraz suszy glebowej. Poszerzenie wiedzy dotyczącej mechanizmów determinujących odporność na suszę i mróz może mieć istotne znaczenie dla uprawy tego gatunku w obliczu dynamicznych zmian klimatycznych, postępującej degradacji środowiska naturalnego oraz wymogów nowoczesnych, zrównoważonych i ekologicznych systemów produkcji rolniczej.

W badaniach wykorzystano linie DH jęczmienia ozimego, o istotnie różnej tolerancji na mróz i suszę glebową, wyprowadzone metodą androgenezy w kulturach pylnikowych, z materiałów hodowlanych dostarczonych przez polskie spółki hodowlane. Wybrane do badań, skrajnie zróżnicowane linie DH posłużyły we wcześniejszych latach realizacji projektu jako materiał do analiz proteomicznych, analiz zawartości hormonów roślinnych biorących udział $\mathrm{w}$ reakcjach obronnych uruchamianych $\mathrm{w}$ odpowiedzi na stres oraz analiz aktywności systemu antyoksydacyjnego. W roku 2018 badania zostały uzupełnione o analizy profilu brasinosteroidów oraz ekspresji genów potencjalnie zaangażowanych $\mathrm{w}$ proces nabywania tolerancji na mróz oraz determinujących poziom tolerancji na suszę.

Analizy przeprowadzono w dwóch układach eksperymentalnych. W pierwszym, ze względu na fakt, iż tolerancja na mróz jest cechą indukowaną pod wpływem aklimatyzacji/hartowania do niskich temperatur, materiał do badań stanowiły siewki w fazie 3-4 liści, umieszczone na okres 3 tyg. w $4 / 2^{\circ} \mathrm{C}$ (dzień/noc). Obiekty kontrolne stanowiły siewki rosnące w optymalnych warunkach termicznych $\left(25 / 17^{\circ} \mathrm{C}\right.$, dzień/noc). W drugim eksperymencie, analizy przeprowadzono na roślinach w fazie kłoszenia, po 3 tygodniu wzrostu w glebie o wilgotności wynoszącej $35 \%$ ppw. Jako obiekty kontrolne wykorzystano rośliny rosnące w warunkach optymalnego nawodnienia (75\% ppw). 
TEMAT BADAWCZY 1: ANALIZA ENDOGENNEJ ZAWARTOŚCI BRASINOSTEROIDÓW (BR) - ZMIANY INDUKOWANE POD WPŁYWEM HARTOWANIA I SUSZY GLEBOWEJ

Analizy BR przeprowadzono wg zmodyfikowanej procedury Tarkowskiej i in. (2016) metodą ultra wysokosprawnej chromatografii cieczowej sprzężonej z tandemowym spektrometrem mas (UHPLC-MS/MS).

Bez względu na warunki wzrostu, w siewkach wszystkich badanych linii DH jęczmienia ozimego wykazano jedynie obecność homokastasteronu $\left(\mathrm{BR}_{12}\right)$. Zawartość $\mathrm{BR}_{12}$ była istotnie uzależniona od cech genotypowych $\mathrm{i}$ istotnie wyższa $\mathrm{w}$ siewkach linii DH wrażliwych na niskie temperatury. Jednak, tylko u linii DH o wyższym poziomie tolerancji na mróz obserwowano istotny, prawie 2-krotny wzrost zawartości tego BR pod wpływem hartowania.

$\mathrm{W}$ roślinach jęczmienia ozimego $\mathrm{w}$ fazie kłoszenia średni poziom $\mathrm{BR}_{12}$ był prawie 5.-krotnie wyższy $\mathrm{w}$ stosunku do poziomu zmierzonego $\mathrm{w}$ roślinach $\mathrm{w}$ fazie siewki. Oprócz $\mathrm{BR}_{12}$ wykryto również obecność kastasteronu $\left(\mathrm{BR}_{2}\right)$, teasteronu $\left(\mathrm{BR}_{8}\right)$ i po raz pierwszy u roślin zbożowych - dolicholidu $\left(\mathrm{BR}_{3}\right)$, jednakże poziom akumulacji tych $\mathrm{BR}$ był znacząco niższy. Poziom wszystkich zidentyfikowanych BR był warunkowany czynnikami o charakterze genotypowo-specyficznym. W większości przypadków deficyt wody wywarł istotny wpływ na poziom akumulacji BR, a reakcja roślin była zróżnicowana u linii DH o różnym poziomie tolerancji na suszę. W warunkach ograniczonej dostępności wody w podłożu, u większość wrażliwych na suszę linii DH obserwowano istotny wzrost zawartości $\mathrm{BR}_{12}, \mathrm{BR}_{8} \mathrm{i} \mathrm{BR}_{3}$. Poziom tych $\mathrm{BR}$ pozostawał nie zmieniony w przypadku linii DH lepiej tolerujących deficyt wody w podłożu. I odwrotnie, linie DH o wyższej tolerancji na suszę reagowały wyraźnym wzrostem zawartości $\mathrm{BR}_{2}$, czego nie obserwowano u linii DH bardziej wrażliwych na ten czynnik stresowy.

Podsumowując uzyskane wyniki, w badanych liniach DH jęczmienia ozimego wykazano specyficzny, związany z fazą rozwojową profil BR, a poziom akumulacji tych związków związany był z poziomem tolerancji na badane, abiotyczne czynniki stresowe. Wykazano, iż zmiany zawartości niektórych BR wydają się być istotnie związane z poziomem odporności na mróz (homokastasteron) i suszę (kastasteron). Natomiast akumulacja innych BR (homokastatsteronu, teasteronu i dolicholodu) w reakcji na deficyt wody może stanowić potencjalny marker identyfikujący genotypy o wysokim poziomie wrażliwości na suszę.

TEMAT BADAWCZY 2: ANALIZY MOLEKULARNE GENÓW POTENCJALNIE ZAANGAŻOWANYCH W DETERMINACJĘ ODPORNOŚCI NA MRÓZ I SUSZĘ

Selekcję wybranych do badań genów przeprowadzono na podstawie wyników analiz proteomicznych wykonanych $\mathrm{w}$ poprzednich latach realizacji projektu, opublikowanych w pracach Gołębiowska i in. (2017a,b). W eksperymencie analizującym wpływ hartowania na ekspresję wybranych genów do analiz wybrano geny kodujące: elongation factor 1 alpha (EF1a), reduktazę Ferrodoksyna - NADP, białko 14-3-3a, $\beta$-fructofuranozydazę oraz białka CBF4B i CBF2A. W eksperymencie dotyczącym molekularnych podstaw odporności jęczmienia ozimego na stres suszy analizowano poziom 
ekspresji genów kodujących aktynę, transketolazę, peryplazmatyczną proteazę serynową, izomerazę triozofosforanową, gen groES kodujący białko z regionem ko-chaperonu oraz gen pfam 14200 kodujący lektynę (białko ricin-type beta-trefoil lectin domain-like).

Analiza ekspresji wybranych genów przeprowadzona techniką ilościowego RT-qPCR wykazała zróżnicowany poziom ekspresji pomiędzy liniami DH jęczmienia ozimego zarówno w przypadku hartowania na mróz, jak i suszy glebowej. Jednakże obserwowane zmiany poziomu ekspresji jedynie częściowo wiązały się ze stopniem tolerancji na badane stresy.

W przypadku hartowania na mróz wyraźnie kontrastowały ze sobą reakcje wrażliwej na mróz linii DH575 oraz mrozoodpornej (a równocześnie nieodpornej na suszę) linii DH602. W przypadku wszystkich genów poziom ich ekspresji był statystycznie istotny, a w przypadku trzech odwrotny był kierunek obserwowanych zmian - u linii DH602 obserwowano hamowanie, a u linii DH575 wzrost poziomu ich ekspresji w porównaniu z kontrolą. Reakcja pozostałych linii DH była jednakowa, pośrednia pomiędzy DH602 i DH575. Być może obserwowane wcześniej różnice w ich mrozoodporności wynikać mogą z innych czynników, niezależnych od zmian obserwowanych w zastosowanym układzie doświadczalnym. W przypadku linii DH534, która jest zarówno mrozoodporna jak i odporna na suszę mogłoby to na przykład wynikać z istotnej w obydwu stresach możliwości zabezpieczania tkanek przed dehydratacją, która indukowana jest nie podczas hartowania na mróz w temperaturach dodatnich lecz dopiero pod wpływem mrozu.

W przypadku suszy poziom ekspresji wszystkich badanych genów obniżył się. Co więcej, u linii DH lepiej tolerujących deficyt wody poziom ekspresji większości analizowanych genów (z wyjątkiem groES) uległ silniejszemu obniżeniu niż u linii DH wrażliwych na suszę. Geny te nie są bezpośrednio związane z tolerancją suszy, kodują natomiast białka uczestniczące w podstawowym metabolizmie komórkowym (proteaza serynowa, izomeraza triozofosforanów) oraz potencjalnie związane z transdukcją sygnału (gen pfam14200 kodujący lektynę).

\section{LITERATURA}

Gołębiowska-Pikania G., Kopeć P., Surówka E., Krzewska M., Dubas E., Nowicka A., Rapacz M., WójcikJagła M., Malaga S., Żur I. 2017 a. Changes in protein abundance and activity involved in freezing tolerance acquisition in winter barley (Hordeum vulgare L.). J. Proteomics 169: 58 - 72.

Gołębiowska-Pikania G., Kopeć P., Surówka E., Janowiak F., Krzewska M., Dubas E., Nowicka A., Kasprzyk J., Ostrowska A., Malaga S., Hura T., Żur I. 2017 b. Changes in protein abundance and activity induced by drought during generative development of winter barley (Hordeum vulgare L.) J. Proteomics 169: $73-86$.

Tarkowska D., Novak O., Oklestkova J., Strnad M. 2016. The determination of 22 natural brassinosteroids in a minute sample of plant tissue by UHPLC-ESI-MS/MS. Anal. Bioanal. Chem. 408: 6799 — 6812. 